\title{
Spectrofluorimetric Study of the Charge-transfer Complexation of Certain Fluoroquinolones with 2,3,5,6-tetrafluoro-p-bezoquinone
}

\author{
${ }^{1}$ D. Geffken and ${ }^{2}$ H. Salem \\ ${ }^{1}$ Institute of Pharmacy, Pharmaceutical Chemistry Department, University of Hamburg \\ Bundesstrasse 45, 29146 Hamburg, Germany \\ ${ }^{2}$ Analytical Chemistry Department, Faculty of Pharmacy, Minia University, Minia, Egypt
}

\begin{abstract}
A highly sensitive spectrofluorimetric method was developed for the first time, for the analysis of ten fluoroquinolones (FQs) antibacterials, namely amifloxacin (AMI), ciprofloxacin (CIP), difloxacin (DIF), enoxacin (ENO), enrofloxacin (ENR), lomefloxacin (LOM), levofloxacin (LEV), norfloxacin (NOR), ofloxacin (OFL) and pefloxacin (PEF) in their pharmaceutical dosage forms or in biological fluids through charge transfer (CT) complex formation with fluoranil (TFQ). The TFQ was found to react with these drugs to produce stable complexes and the fluorescence intensity of the complexes was greatly enhanced. The formation of such complexes was also confirmed by both infrared and ultraviolet-visible measurements. The different experimental parameters that affect the fluorescence intensity were carefully studied. At the optimum reaction conditions, the drug-TFQ complexes showed excitation maxima ranging from 270 to $285 \mathrm{~nm}$ and emission maxima ranging from 450 to $460 \mathrm{~nm}$. Rectilinear calibration graphs were obtained in the concentration range 0.02 to $3.1 \mu \mathrm{g}$ $\mathrm{mL}^{-1}$ for the studied drugs. The method has been successfully applied to determine their pharmaceutical dosage forms with good precision and accuracy compared to official and reported methods as revealed by $t$ - and $F$-tests. They also applied for the determination of studied drugs in human urine samples.
\end{abstract}

Key words: Fluoroquinolones, $p$-fluoranil, charge-transfer complexes, spectrofluorimetry

\section{INTRODUCTION}

Flurorquinolones (FQs) are a class of important synthetic antibiotics, which are active against both Gram (+) and Gram (-) bacteria through inhibition of their DNA gyrase ${ }^{[1]}$, also they have some activity against myobacteria, mycoplasmas and rickettsias.

Several chromatographic methods have been reported for determination of these compounds, amifloxacin $(\mathrm{AMI})^{[2]}$, ciprofloxacin $(\mathrm{CIP})^{[3]}$, difloxacin $(\mathrm{DIF})^{[4]}$, enoxacin $(\mathrm{ENO})^{[5]}$, enrofloxacin $(\mathrm{ENR})^{[6]}$, lomefloxacin $(\mathrm{LOM})^{[7]}$, levofloxacin $(\mathrm{LEV})^{[8]}$, norfloxacin $(\mathrm{NOR})^{[9]}$, ofloxacin $(\mathrm{OFL})^{[10]}$ and pefloxacin $(\mathrm{PEF})^{[11]}$ were determined by highperformance liquid chromatography (HPLC). Various spectrophotometric methods were described for determination of CIP, ENR and $\mathrm{PEF}^{[12]}, \mathrm{NOR}^{[13]}$ and $\mathrm{LEV}^{[14]}$ by charge-transfer complex formation with chloranilic acid, tetracyanoquinodimethane and tetracyanoethylene. In addition, several methods have been reported for their determination such as spectrophotometry ${ }^{[15,16]}$, fluorimetry ${ }^{[17-19]}$, polarography ${ }^{[20]}$ voltametric ${ }^{[21]}$ and capillary electrophoresis $^{[22]}$. HPLC methods generally require complex and expensive equipment, provision for use and disposal of solvents, labor-intensive sample preparation procedure and personal skilled in chromatographic techniques. Charge-transfer spectrofluorimetry (CTF) has been found to be useful for the determination of quinolone in real samples (2327), showing several advantages such as low interference level, low detection limit, high sensitivity, good analytical selectivity, easy and less time consuming comparing with the above methods. A new spectrofluorimetric method for determination of AMI, CIP, DIF, ENO, ENR, LOM, LEV, NOR, OFL and PEF was reported through CT complexation with TFQ in this paper, having been satisfactory applied to the determination of studied drugs in commercial formulations and urine samples.

\section{MATERIALS AND METHODS}

Reagents: All solvents used were of analytical reagent grade. Methanol, ethanol, isopropanol, acetone, acetonitrile and chloroform (Merck KGaA, Germany). TFQ (Sigma Chemical Co.,USA) was prepared $4 \times 10^{-4}$ mol L ${ }^{-1}$ in acetone, solution was found be stable for at least 1 week at $4{ }^{\circ} \mathrm{C}$. Samples of $\mathrm{FQs}$ were generously supplied by their respective manufactures: AMI (Sterling Winthrop Inc., USA); DIF (Abbott Laboratories, North Chicago, USA); NOR (Eipico, Cairo, Egypt); OFL (Hoechst AG, Frankfurt, Germany); CIP (Miles Inc. Pharmaceutical Division,

Corresponding Author: $\quad$ H. Salem, Analytical Chemistry Department, Faculty of Pharmacy, Minia University, Minia, Egypt, Tel: +20-10-605-0029, Fax: +20-86-2369-075, E-mail: h_salem_eg@yahoo.com 
West Haven, Germany); PEF (Rhone-Poulenc Rorer, Neuilly/Seine, France); LOM (Searle, Illinois, USA); ENO, ENR and LEV (Sigma Chem. Co., USA) and were used without further purification. Stock standard solution of $100 \mu \mathrm{g} \mathrm{mL}^{-1}$ was prepared by dissolving ten drugs standard samples in methanol as needed. Working standard solutions were prepared by dilution of stock standard solution with acetone. Stock standard solutions were stable for several weeks at room temperature.

Pharmaceutical formulations: The following available commercial preparations were analyzed: Spectrama ${ }^{\circledR}$ tablets (Amoun Pharmaceutical Industries Co., Cairo, Egypt) labeled to contain 400 NOR per tablet; Neofloxacin ${ }^{\circledR}$ tablets (Alexandria Co. for Pharmaceuticals, Alexandria, Egypt) labeled to contain 400 mg NOR tablet; Norbactin ${ }^{\circledR}$ (Chem. Ind. Co., Giza, Egypt) labeled to contain $400 \mathrm{mg}$ NOR per tablet; Tarivid $^{\circledR}$ tablets (Hoechst Orient, Cairo, Egypt, under license of Hoechst AG, Frankfurt, Germany) labeled to contain $200 \mathrm{mg}$ OFL per tablet; Kirol ${ }^{\circledR}$ tablets (Amoun Pharmaceutical Industries Co., Cairo, Egypt) labeled to contain $200 \mathrm{mg}$ OFL per tablet; Mefoxin ${ }^{\circledR}$ tablets (Misr Co. for Pharmaceutical Industries, Cairo, Egypt) labeled to contain $250 \mathrm{mg}$ CIP per tablet; Serviflox ${ }^{\circledR}$ tablets (Under Licence from Biochemie Kundi Austria), labeled to contain 250 CIP per tablet; Ciprohexal ${ }^{\circledR}$ tablets (Hexal Co.,, Germany) labeled to contain 500 mg CIP per tablet; Cipro ${ }^{\circledR}$ otic drops (Chem. Indus. Develop. Co.,Giza, Egypt) labeled to contain $3.5 \mathrm{mg}$ CIP per each mL; Globacin ${ }^{\circledR}$ tablets (Global Napi Pharm. Egypt) labeled to contain $400 \mathrm{mg}$ PEF per tablet; Peflacin ${ }^{\circledR}$ ampoules (Rhone-Poulenc Rorer, Neuilly/Seine, France) labeled to contain $400 \mathrm{mg}$ PEF and $15.3 \mathrm{mg}$ sodium ascorbate per $5 \mathrm{~mL}$ ampoule; Tavanic $^{\circledR}$ tablets (Under Licence of Aventis Pharma Germany) labeled to contain $500 \mathrm{mg}$ LEV per tablet.

Apparatus: Fluorescence signals were measured on an FP-750 spectrofluorometer (Jasco, Germany) connected to an IBM computer loaded with FLwinlab $^{\text {TM }}$ application software 4.00.02 version, was used. All the measurements took place in a standard $10 \mathrm{~mm}$ pathlength quartz cell, thermo stated at $25.0 \pm 0.5{ }^{\circ} \mathrm{C}$, with $2.5 \mathrm{~nm}$ bandwidth for the emission and excitation monochromators.

A UV-Lambda $40 \quad$ ultraviolet-visible spectrophotometer ((Perkin Elmer instruments, USA) was used for the absorbance measurements.

An infrared spectrometer FT-400/600Plus series (Jasco, Germany) was used for recording IR spectrum.

General procedure: A suitable amount of drug solution was pipetted into a $10 \mathrm{~mL}$ volumetric flask, 1.0 $\mathrm{mL}$ of TFQ solution was added and the solution was diluted to volume with acetone and mixed thoroughly.
The solution were thermo stated at $25.0 \pm 0.5{ }^{\circ} \mathrm{C}$ and the fluorescence intensities of CT complexes of AMI, CIP, DIF, ENO, ENR, LOM, LEV, NOR, OFL and PEF were measured at 456, 460, 458, 450, 452, 453, 456, 455,455 and $451 \mathrm{~nm}$ using an excitation wavelength of 280, 270, 279, 282, 283, 285, 284, 276, 271 and $274 \mathrm{~nm}$ against a blank solution, respectively. The calibration graph was constructed in the same way with studied drugs solutions of known concentrations. The amount of drugs was computed from their calibration graphs.

Analysis of tablets: An accurately weighed amount, equivalent to $10 \mathrm{mg}$ of each drug from composite of 20 powdered tablets, was transferred into a $100 \mathrm{~mL}$ calibrated flask and diluted to the mark with the appropriate solvent, sonicated for $20 \mathrm{~min}$ and filtered off to obtain solutions of $100 \mu \mathrm{g} \mathrm{mL}^{-1}$. Further dilutions were made to obtain sample solution and the general procedures were proceeding described earlier.

Analysis of ampoules: A volume equivalent to $10 \mathrm{mg}$ of each drug was transferred into $100 \mathrm{~mL}$ calibrated flask and diluted to the mark with the appropriate solvent to obtain solution of $100 \mu \mathrm{g} \mathrm{mL} \mathrm{m}^{-1}$. Further dilutions were made to obtain sample solution and the general procedures were proceeding described earlier.

Analysis of drops: One milliliter of the drops was transferred into a $100 \mathrm{~mL}$ calibrated flask and diluted to the mark with the appropriate solvent to obtain a solution of $30 \mu \mathrm{g} \mathrm{mL}^{-1}$. Further dilutions were made to obtain sample solution and the general procedures were proceeding described earlier.

Preparation of the complexes for infrared: To $5 \mathrm{~mL}$ of $0.05 \mathrm{~mol} \mathrm{~L}^{-1}$ TFQ in acetone and $5 \mathrm{~mL}$ of $0.05 \mathrm{~mol}$ $\mathrm{L}^{-1}$ each investigated drug in acetone was added in around bottom flask containing $50 \mathrm{~mL}$ of acetone and stirred for $30 \mathrm{~min}$. The solvent was evaporated under reduced pressure and the resulting oily residues were dried over calcium chloride.

Analysis of human urine: Dilute urine samples of a healthy subject who has taken, orally, FQs tablets at specific times, in $5 \mathrm{~mL}$ sample solution were transferred into a separating funnel and shaken well for $3 \mathrm{~min}$. Then $5 \mathrm{~mL}$ of $0.2 \mathrm{~mol} \mathrm{~L}^{-1}$ phosphate buffer solution ( $\mathrm{pH}$ 7.0) was added and the mixture shaken and extracted with $3 \times 10 \mathrm{~mL}$ of dichloromethane chloroform $(1: 1 \mathrm{v} / \mathrm{v})$ mixture. The organic layer was filtered over anhydrous sodium sulfate. The extract was dried under nitrogen gas at room temperature and residue dissolved in least amount of acetone, transferred into a $10 \mathrm{~mL}$ volumetric flask and procedures were proceeding described earlier. 


\section{RESULTS AND DISCUSSION}

Excitation spectra and emission spectra: Solution of the studied drugs have native fluorescence, however in presence of TFQ, the fluorescence intensity increases substantially, the sensitivity is enhanced by $22-54$ fold (Fig. 1). Indicated CT complexes formation between the investigated drugs and TFQ, these drugs were probably through the lone pair of electron donated by the $\mathrm{N}$ atom in piperazinyl of FQs (n-donor) to TFQ $(\pi$ acceptor).

Effect of reaction temperature: The effect of temperature on the formed CT complexes was studied in the range of $10-60{ }^{\circ} \mathrm{C}$. All the formed complexes were stable up to $40^{\circ} \mathrm{C}$, at temperatures higher than 40 ${ }^{\circ} \mathrm{C}$, the relative fluorescence intensity decreases due to dissociation of the complexes at higher temperatures. Similarly, the fluorescence intensity was found to depend on temperature of CT complexes with studied drugs is small in the range of $10-4040{ }^{\circ} \mathrm{C}$, thus the determination of studied drugs were carried out at $25 \pm 0.5{ }^{\circ} \mathrm{C}$. It was further found that takes $30 \mathrm{~min}$ to form the complexes completely which were stable for at least $24 \mathrm{~h}$.

Effect of TFQ concentration: The influence of CT reagent concentration was studied in the range $4 \times 10^{-5}$ mol L $\mathrm{L}^{-1}-4 \times 10^{-3} \mathrm{~mol} \mathrm{~L}^{-1}$. The relative fluorescence intensity increased with increasing TFQ concentration up to $4 \times 10^{-4} \mathrm{~mol} \mathrm{~L}^{-1}$ but leveled off at higher concentrations. Experiment indicated that $1.0 \mathrm{~mL}$ TFQ solution is enough for each drug, thus the final TFQ concentration of $4 \times 10^{-4} \mathrm{~mol} \mathrm{~L}^{-1}$ was used for all of the studied drugs.

Effect of solvent: Fluorescence spectral characteristics of AMI, CIP, DIF, ENO, ENR, LOM, LEV, NOR, OFL and PEF in different solvents are compared. The studied solvents involved water, methanol, ethanol, isopropanol, acetone, acetoniltrile and chloroform. Experimental results indicated that acetone gave the maximum and stable fluorescence emission for studied drugs.

Effect of CT reagent: The influence of the CT reagent on the relative fluorescence intensity of all the formed CT complexes with FQs was studied at their respective maxima using TFQ, TCNQ, TCNE, CL and DDQ as model electron acceptors. The results show that TFQ is most sensitive CT reagent for the studied drugs. In general, the order of decreasing sensitivity is TFQ > TCNQ $>$ TCNE $>$ DDQ $>$ Cl (Fig. 2).

nvestigations on the structure of the charge-transfer complexes: The fluorescence intensity increases substantially indicated the possible CT complexes formation of the type $n-\pi$ complexes.

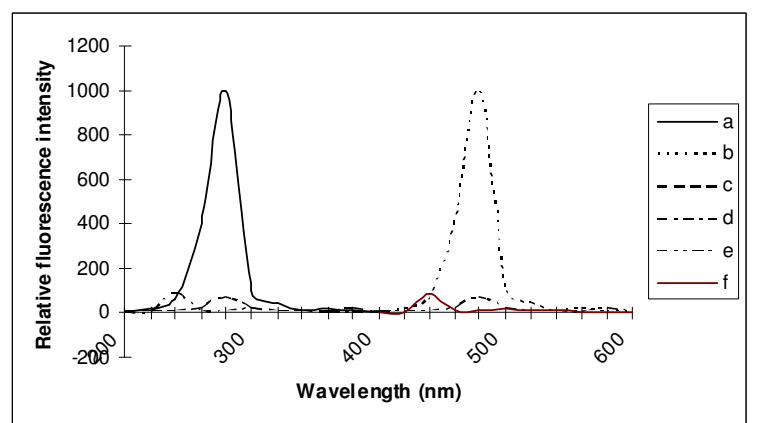

Fig. 1: Fluorescence spectra of CIP (c and d, $0.8 \mu \mathrm{g} \mathrm{mL}^{-1}$ ), TFQ ( $\mathrm{e}$ and $\mathrm{f}, 4 \times 10^{-4} \mathrm{~mol} \mathrm{~L}^{-1}$ ) and CIP-TFQ ( $\mathrm{a}$ and b). Excitation spectra (a, c and e) and emission spectra (b, d and f)

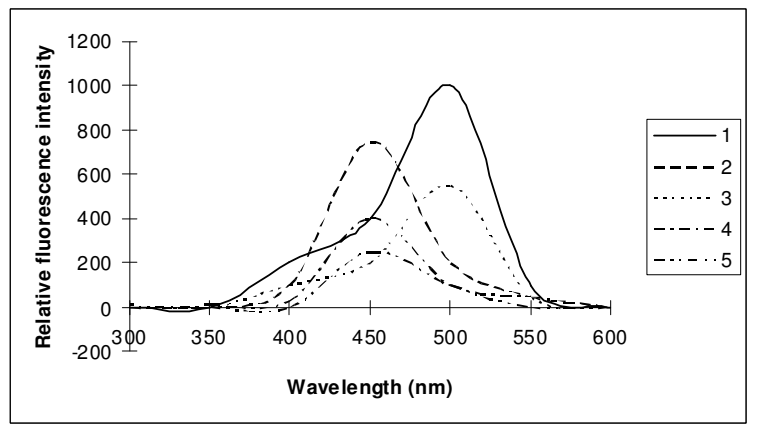

Fig. 2: Fluorescence emission spectra of: (1) CIP (0.8 $\left.\mu \mathrm{g} \mathrm{mL}^{-1}\right)$ with TFQ $\left(4 \times 10^{-4} \mathrm{~mol} \mathrm{~L}^{-1}\right)$. (2) CIP $(0.8$ $\left.\mu \mathrm{g} \mathrm{mL}^{-1}\right)$ with TCNQ $\left(4 \times 10^{-4} \mathrm{~mol} \mathrm{~L}^{-1}\right)$. (3) CIP $(0.8$ $\left.\mu \mathrm{g} \mathrm{mL}^{-1}\right)$ with TCNE $\left(4 \times 10^{-4} \mathrm{~mol} \mathrm{~L}^{-1}\right)$. (4) CIP $(0.8$ $\left.\mu \mathrm{g} \mathrm{mL}^{-1}\right)$ with DDQ $\left(4 \times 10^{-4} \mathrm{~mol} \mathrm{~L}^{-1}\right)$. (5) CIP $(0.8$ $\left.\mu \mathrm{g} \mathrm{mL} \mathrm{m}^{-1}\right)$ with CL $\left(4 \times 10^{-4} \mathrm{~mol} \mathrm{~L}^{-1}\right)$

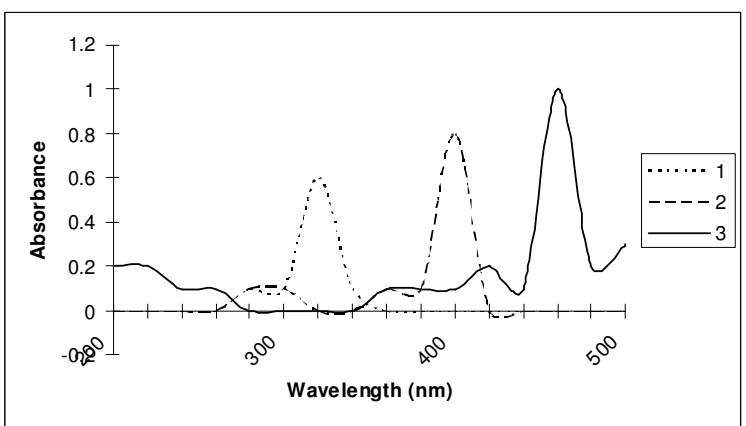

Fig. 3: Absorption spectra: (1) CIP $\left(0.8 \mu \mathrm{g} \mathrm{mL}^{-1}\right)$; (2) TFQ $\left(4 \times 10^{-4} \mathrm{~mol} \mathrm{~L}^{-1}\right)$ and (3) CIP-TFQ against acetone blank

Both IR and UV measurements also confirmed the formation of such complexes. The majority of infrared measurements on such CT complexes have been concerned with the shifts in the vibrational frequencies of donors or acceptors. Decreases in the vibration frequency of a particular band have been used as evidence for a particular site of a CT interaction ${ }^{[26]}$. The infrared spectra of the complexes show some difference compared with the sum of the spectra of the two components. This was used to distinguish between weak CT complexes and the products of electrontransfer $^{[28]}$. 
Table 1: Characteristic bands $\left(\mathrm{Cm}^{-1}\right)$ of IR spectra of TFQ and FQTFQ complexes

\begin{tabular}{llll}
\hline Compounds & $\mathrm{C}=\mathrm{O}$ & $\mathrm{C}=\mathrm{C}$ & $\mathrm{C}-\mathrm{F}$ \\
\hline TFQ & 1669 & 1333 & 993 \\
AMI-TFQ & 1630 & 1270 & 940 \\
CIP-TFQ & 1635 & 1275 & 944 \\
DIF-TFQ & 1630 & 1269 & 950 \\
ENO-TFQ & 1610 & 1261 & 939 \\
ENR-TFQ & 1600 & 1255 & 941 \\
LOM-TFQ & 1630 & 1273 & 944 \\
LEV-TFQ & 1639 & 1290 & 954 \\
NOR-TFQ & 1630 & 1271 & 944 \\
OFL-TFQ & 1623 & 1289 & 949 \\
PEF-TFQ & 1619 & 1280 & 940 \\
\hline
\end{tabular}

Table 2: Wavelength $(\mathrm{nm})$ of absorption maximum for FQs and FQ-TFQ complexes

\begin{tabular}{lll}
\hline Drugs & FQs & FQ-TFQ \\
\hline AMI & 294 & 466 \\
CIP & 310 & 468 \\
DIF & 312 & 472 \\
ENO & 282 & 464 \\
ENR & 299 & 464 \\
LOM & 315 & 475 \\
LEV & 298 & 470 \\
NOR & 276 & 460 \\
OFL & 300 & 469 \\
PEF & 279 & 462 \\
\hline
\end{tabular}

The IR spectra of TFQ show strong bands at 1699, 1333 and $993 \mathrm{~cm}^{-1}$. These bands were shifted in the spectra of the complexes with the investigated compounds (Table 1).

Figure 3 and Table 2 show maximum absorbance of ten FQs in acetone ranging from 276 to $315 \mathrm{~nm}$. When TFQ solution was added to studied drugs solution, the studied drugs solution with TFQ cause an immediate change in the absorption spectrum with new characteristic bands at $460-475 \mathrm{~nm}$. The appearance of a new band in the visible region of the spectrum was evidence for the formation of a CT complex between the studied components and TFQ.

Mechanism of reaction: TFQ is an $\pi$-acceptor, AMI, CIP, DIF, ENO, ENR, LOM, LEV, NOR, OFL and PEF are nitrogenous compounds. So CT complexes can be formed with these drugs. Molar ration of the reactants in the CT complex was determined by Job's method of continuous variation ${ }^{[29]}$ and Yoe and Jones method of mole ratio ${ }^{[30]}$ and it was found to be 1:1 for studied drugs with TFQ. This ratio may be due to the presence of the fluorine atom acting as an electron drawing group in the molecule of FQs. The benzene ring has lower electron density, but nitrogen atom in 4 of piperazinyl has more electron density and less sterically hindered. So $n-\pi$ CT complexes were formed (Table 3).

Analytical parameters: Under the experimental conditions described, standard calibration curves of CT complexes for AMI, CIP, DIF, ENO, ENR, LOM, LEV, NOR, OFL and PEF with TFQ were constructed by plotting fluorescence intensity versus concentration, the linear regression equation for each method are listed in Table 4. The correlation coefficients ranged from 0.9993 to 0.9999 , indicating good linearity. The small value of variance confirmed the small degree of scattering of the experimental data points around the regression line.

Precision of the proposed methods was determined in each concentration range, by 10 measurements carried out on different days within 1 week of different solution of AMI, CIP, DIF, ENO, ENR, LOM, LEV, NOR, OFL and PEF. Target concentrations corresponded to middle values in each range. Table 4 gives a R.S.D. (within-day and between-day) of solutions of $0.01,0.10$ and $1.00 \mu \mathrm{g} \mathrm{mL} \mathrm{m}^{-1}$ were determined by using the proposed procedure.

Analysis of pharmaceutical formulations: The proposed methods were applied to the determination of the studied drugs in their pharmaceutical formulations. Five replicate determinations were made. Satisfactory results were obtained for studied drugs (Table 6). Moreover, to check the validity of the proposed methods, the standard addition method was applied by adding AMI, CIP, DIF, ENO, ENR, LOM, LEV, NOR, OFL and PEF to the previously analyzed pharmaceutical formulations. The recovery of each drug was calculated by comparing the concentration obtained from the (spiked) mixtures with those of the pure drugs. Table 5 shows the results of analysis of the commercial pharmaceutical formulations and the recovery study (standard addition method) of studied drugs. In comparison of the results obtained by the proposed method with those obtained by literature method $^{[16]}$ indicated that the accuracy is satisfactory. The obtained high-intensity fluorescence bands and the very low reagent background make these procedures suitable for the routine quality control analysis of the investigated compounds with minimum interference. The proposed and reference methods were applied to the determination of the studied drugs in pharmaceutical formulations containing different FQs (Table 6). In the $t$ and $F$ tests, no significant differences were found between the calculated and the theoretical values (95\% confidence) of both the proposed and the reference methods. This indicates similar precision and accuracy.

Analysis of human urine: The proposed method was applied to determine CIP as a representative example of the studied drugs in human urine samples from healthy volunteers who received a single oral dose of $500 \mathrm{mg}$ CIP. The urine samples of individuals were collected at $6,12,24$ and $36 \mathrm{hr}$ after oral administration of CIP tablets. In this case, the high performance liquid chromatography (HPLC) method proposed by Wong et al. was used as a reference method ${ }^{[31]}$. The results obtained summarized in Table 7, show that both methods (spectrofluorimetric and chromatographic) 
Table 3: Structures of the investigated drugs CT complexes with TFQ

\begin{tabular}{|c|c|c|c|c|c|c|c|c|c|c|}
\hline \multicolumn{2}{|c|}{ Compound } & $\mathrm{R}_{1}$ & & \multicolumn{2}{|l|}{$\mathrm{R}_{2}$} & \multicolumn{2}{|l|}{$\mathrm{R}_{3}$} & \multicolumn{3}{|c|}{$\mathrm{R}_{4}$} \\
\hline \multicolumn{2}{|c|}{ 1- Amifloxacin } & $\mathrm{NHCH}_{3}$ & & \multicolumn{2}{|l|}{$\mathrm{H}$} & \multicolumn{2}{|l|}{$\mathrm{CH}_{3}$} & \multicolumn{2}{|c|}{$\mathrm{H}$} & \\
\hline \multicolumn{2}{|c|}{ 2- Ciprofloxacin } & $\mathrm{CH}_{2}$ & & \multicolumn{2}{|l|}{$\mathrm{H}$} & \multicolumn{2}{|l|}{$\mathrm{H}$} & \multicolumn{2}{|c|}{$\mathrm{H}$} & \\
\hline \multirow{3}{*}{\multicolumn{2}{|c|}{$\begin{array}{l}\text { 3- Difloxacin } \\
\text { 4- Enoxacin } \\
\text { 5- Enrofloxacin }\end{array}$}} & $\mathrm{C}_{6} \mathrm{H}_{4}-\mathrm{F}$ & & \multirow{3}{*}{\multicolumn{2}{|c|}{$\begin{array}{l}\mathrm{H} \\
\mathrm{H} \\
\mathrm{H}\end{array}$}} & \multirow{3}{*}{\multicolumn{2}{|c|}{$\begin{array}{l}\mathrm{CH}_{3} \\
\mathrm{H} \\
\mathrm{C}_{2} \mathrm{H}_{5}\end{array}$}} & \multicolumn{3}{|c|}{$\mathrm{H}$} \\
\hline & & $\mathrm{C}_{2} \mathrm{H}_{5}$ & & & & & & \multirow{2}{*}{\multicolumn{2}{|c|}{$\begin{array}{l}\mathrm{H} \\
\mathrm{H}\end{array}$}} & \\
\hline & & $\mathrm{CH}_{2}$ & & & & & & & & \\
\hline \multicolumn{2}{|c|}{$\begin{array}{l}\text { 6- Lomefloxacin } \\
\text { 7- Levofloxacin }\end{array}$} & $\mathrm{C}_{2} \mathrm{H}_{5}$ & & \multicolumn{2}{|l|}{$\mathrm{F}$} & $\begin{array}{l}\mathrm{H} \\
\mathrm{CH}_{3}\end{array}$ & & \multicolumn{2}{|c|}{$\begin{array}{l}\mathrm{CH}_{3} \\
\mathrm{H}\end{array}$} & \\
\hline \multicolumn{2}{|c|}{$\begin{array}{l}\text { 8- Norfloxacin } \\
\text { 9- Ofloxacin }\end{array}$} & $\mathrm{C}_{2} \mathrm{H}_{5}$ & & \multicolumn{2}{|l|}{$\mathrm{H}$} & \multicolumn{2}{|l|}{$\begin{array}{l}\mathrm{H} \\
\mathrm{CH}_{3}\end{array}$} & \multicolumn{2}{|c|}{$\begin{array}{l}\mathrm{H} \\
\mathrm{H}\end{array}$} & \\
\hline 10-Peflc & xacin & $\mathrm{C}_{2} \mathrm{H}_{5}$ & & $\mathrm{H}$ & & $\mathrm{CH}_{3}$ & & \multicolumn{2}{|c|}{$\mathrm{H}$} & \\
\hline Drugs & $\lambda_{\mathrm{ex}} / \lambda_{\mathrm{em}}$ & L.R. & L.D. & L.Q. & $\mathrm{b}$ & S.D. & $\mathrm{a}$ & $\mathrm{Sa}$ & $\mathrm{V}$ & $\mathrm{r}$ \\
\hline AMI & $280 / 456$ & $0.08-2.5$ & 0.008 & 0.025 & 423.77 & 1.14 & 1.32 & 0.12 & 0.018 & 0.9998 \\
\hline CIP & $270 / 460$ & $0.04-1.4$ & 0.012 & 0.039 & 387.96 & 1.17 & 1.00 & 0.87 & 0.123 & 0.9999 \\
\hline DIF & $279 / 458$ & $0.07-3.1$ & 0.022 & 0.070 & 287.35 & 0.94 & 0.92 & 0.02 & 0.024 & 0.9993 \\
\hline ENO & $282 / 450$ & $0.03-2.0$ & 0.004 & 0.015 & 619.48 & 1.16 & 1.11 & 0.01 & 0.053 & 0.9999 \\
\hline ENR & $283 / 452$ & $0.04-2.8$ & 0.006 & 0.021 & 496.00 & 1.11 & 1.27 & 0.06 & 0.025 & 0.9994 \\
\hline LOM & $285 / 453$ & $0.02-2.7$ & 0.008 & 0.031 & 145.97 & 1.02 & 1.62 & 0.04 & 0.062 & 0.9995 \\
\hline LEV & $284 / 456$ & $0.04-2.8$ & 0.004 & 0.015 & 299.03 & 1.21 & 1.04 & 0.06 & 0.058 & 0.9996 \\
\hline NOR & $276 / 455$ & $0.02-2.9$ & 0.012 & 0.041 & 321.98 & 1.12 & 1.21 & 0.06 & 0.082 & 0.9994 \\
\hline OFL & $271 / 455$ & $0.03-2.2$ & 0.009 & 0.080 & 762.93 & 1.11 & 1.71 & 0.01 & 0.027 & 0.9996 \\
\hline PEF & $274 / 451$ & $0.05-2.6$ & 0.005 & 0.015 & 265.87 & 0.99 & 1.81 & 0.07 & 0.012 & 0.9999 \\
\hline
\end{tabular}

$\overline{\lambda_{\mathrm{ex}}} / \lambda_{\mathrm{em}}(\mathrm{nm})$; L.R. (linear range $\mu \mathrm{g} \mathrm{ml}^{-1}$ ); L.D. (Limit of detection $\mu \mathrm{g} \mathrm{ml}^{-1}$ ); L.Q. (Limit of quantitation $\mu \mathrm{g} \mathrm{ml}{ }^{-1}$ ); b (Slope); S.D. (Standard deviation of slope); a (Intercept of the ordinate); Sa (Standard deviation of the intercept of the ordinate); V (Variance); $r$ (Correlation coefficients).

Table 5: Precision results of FQs $(n=11)$

\begin{tabular}{|c|c|c|c|c|c|c|}
\hline \multirow[b]{3}{*}{ Drug } & \multicolumn{6}{|c|}{ Concentration $\left(\mu \mathrm{g} \mathrm{ml}^{-1}\right)$} \\
\hline & \multicolumn{3}{|c|}{ Within-day R.S.D.(\%) } & \multicolumn{3}{|c|}{ Between-day R.S.D. (\%) } \\
\hline & 0.01 & 0.10 & 1.00 & 0.01 & 0.10 & 1.00 \\
\hline AMI & 1.2 & 1.1 & 1.9 & 1.0 & 1.8 & 1.5 \\
\hline CIP & 0.8 & 1.8 & 1.6 & 1.3 & 1.4 & 1.7 \\
\hline DIF & 1.3 & 1.8 & 1.5 & 0.8 & 1.5 & 1.3 \\
\hline ENO & 1.7 & 1.4 & 1.4 & 1.2 & 1.0 & 1.5 \\
\hline ENR & 1.5 & 1.9 & 0.9 & 1.5 & 1.0 & 1.1 \\
\hline LOM & 1.9 & 1.5 & 1.4 & 1.7 & 1.6 & 1.3 \\
\hline LEV & 1.6 & 1.2 & 1.5 & 1.5 & 1.4 & 1.9 \\
\hline NOR & 1.6 & 1.4 & 1.8 & 1.2 & 1.9 & 1.2 \\
\hline OFL & 1.1 & 1.6 & 1.5 & 1.5 & 1.3 & 1.2 \\
\hline PEF & 1.7 & 1.8 & 0.9 & 1.1 & 1.8 & 1.5 \\
\hline
\end{tabular}

yield values within the same range when tested by using statistical procedures.

The accuracy was assessed by investigating the recovery of each of the studied drugs at four concentration levels covering the specified range (five replicates of each concentration). The results showed average percentage recoveries were $95.9 \pm 1.1$ with standard deviations less than 2.0 for human urine, indicating both good accuracy and precision (Table 8).

The increase in sensitivity obtained with the proposed method, compared with other methods is very substantial. Comparison with other proposed method 
Am. J. Applied Sci., 3 (8): 1952-1960, 2006

Table 6: Determination of drugs in pharmaceutical formulation using TFQ

\begin{tabular}{|c|c|c|c|}
\hline Drug & & Proposed method & Reference method [16] \\
\hline \multirow{4}{*}{ Spectrama ${ }^{\circledR}$ Tablets } & $\mathrm{X} \pm \mathrm{SD}$ & $97.21 \pm 0.60$ & $97.00 \pm 0.66$ \\
\hline & V & 0.35 & 0.40 \\
\hline & $\mathrm{t}$ & 0.91 & 0.02 \\
\hline & $\mathrm{F}$ & 1.10 & 1.20 \\
\hline \multirow[t]{4}{*}{ Neofloxacin ${ }^{\circledR}$ Tablets } & $\mathrm{X} \pm \mathrm{SD}$ & $100.11 \pm 0.62$ & $99.11 \pm 0.59$ \\
\hline & V & 0.45 & 0.35 \\
\hline & $\mathrm{t}$ & 0.41 & 0.31 \\
\hline & $\mathrm{F}$ & 1.21 & 1.03 \\
\hline \multirow{4}{*}{ Norbactin ${ }^{\circledR}$ Tablets } & $\mathrm{X} \pm \mathrm{SD}$ & $99.92 \pm 1.00$ & $99.00 \pm 0.90$ \\
\hline & $\mathrm{V}$ & 1.00 & 0.81 \\
\hline & $\mathrm{t}$ & 0.65 & 0.03 \\
\hline & $\mathrm{F}$ & 1.01 & 1.13 \\
\hline \multirow[t]{4}{*}{ Tarivid $^{\circledR}$ Tablets } & $\mathrm{X} \pm \mathrm{SD}$ & $99.89 \pm 79$ & $100.01 \pm 0.70$ \\
\hline & $\mathrm{V}$ & 0.55 & 0.49 \\
\hline & $\mathrm{t}$ & 0.87 & 0.04 \\
\hline & F & 1.02 & 1.11 \\
\hline \multirow[t]{4}{*}{ Kirol $^{\circledR}$ Tablets } & $\mathrm{X} \pm \mathrm{SD}$ & $99.76 \pm 0.53$ & $100.36 \pm 0.48$ \\
\hline & V & 0.34 & 0.23 \\
\hline & $\mathrm{t}$ & 0.59 & 00.0 \\
\hline & $\mathrm{F}$ & 1.21 & 1.09 \\
\hline \multirow[t]{4}{*}{ Mefoxin ${ }^{\circledR}$ Tablets } & $\mathrm{X} \pm \mathrm{SD}$ & $100.11 \pm 0.56$ & $99.98 \pm 0.54$ \\
\hline & V & 0.41 & 0.29 \\
\hline & $\mathrm{t}$ & 0.29 & 0.35 \\
\hline & $\mathrm{F}$ & 1.61 & 1.21 \\
\hline \multirow[t]{4}{*}{ Serviflox ${ }^{\circledR}$ Tablets } & $\mathrm{X} \pm \mathrm{SD}$ & $100.7 \pm 0.90$ & $101.12 \pm 0.88$ \\
\hline & $\mathrm{V}$ & 0.61 & 0.77 \\
\hline & $\mathrm{t}$ & 0.81 & 1.41 \\
\hline & $\mathrm{F}$ & 1.09 & 1.01 \\
\hline \multirow[t]{4}{*}{ Cipro otic ${ }^{\circledR}$ Drops } & $\mathrm{X} \pm \mathrm{SD}$ & $98.86 \pm 0.69$ & $100.01 \pm 0.90$ \\
\hline & $\mathrm{V}$ & 0.56 & 0.81 \\
\hline & $\mathrm{t}$ & 0.83 & 0.20 \\
\hline & $\mathrm{F}$ & 1.57 & 1.02 \\
\hline \multirow[t]{4}{*}{ Globacin ${ }^{\circledR}$ Tablets } & $\mathrm{X} \pm \mathrm{SD}$ & $100.51 \pm 0.71$ & $99.11 \pm 0.50$ \\
\hline & $\mathrm{V}$ & 0.48 & 0.25 \\
\hline & $\mathrm{t}$ & 0.57 & 0.29 \\
\hline & $\mathrm{F}$ & 1.15 & 1.32 \\
\hline \multirow[t]{4}{*}{ Peflacin ${ }^{\circledR}$ Ampoules } & $\mathrm{X} \pm \mathrm{SD}$ & $99.20 \pm 0.51$ & $99.99 \pm 0.39$ \\
\hline & $\mathrm{V}$ & 0.38 & 0.15 \\
\hline & $\mathrm{t}$ & 0.89 & 0.04 \\
\hline & $\mathrm{F}$ & 1.99 & 1.07 \\
\hline \multirow[t]{4}{*}{ Tavanic $^{\circledR}$ Tablets } & $\mathrm{X} \pm \mathrm{SD}$ & $100.2 \pm 0.61$ & $99.80 \pm 0.50$ \\
\hline & $\mathrm{V}$ & 0.45 & 0.25 \\
\hline & $\mathrm{t}$ & 0.79 & 0.53 \\
\hline & $\mathrm{F}$ & 1.81 & 1.44 \\
\hline Ciprohexal ${ }^{\circledR}$ Tablets & $\mathrm{X} \pm \mathrm{SD}$ & $100.02 \pm 0.55$ & \\
\hline
\end{tabular}

Three and six determinations were used for the reported and the reference methods, respectively. The tabulated values of $\mathrm{t}$ and $\mathrm{F}$ at $95 \%$ confidence limit are $\mathrm{t}=2.23$ and $\mathrm{F}=5.79$.

Table 7: Determination of CIP in human urine samples

\begin{tabular}{|c|c|c|c|c|}
\hline \multirow[b]{2}{*}{ Sample b } & \multicolumn{2}{|l|}{ CIP found ${ }^{\mathrm{a}}\left(\mu \mathrm{g} \mathrm{ml}^{-1}\right)$} & \multirow[b]{2}{*}{$\mathrm{t}$} & \multirow[b]{2}{*}{$\mathrm{P}^{\text {value }}{ }^{\mathrm{c}}(\%)$} \\
\hline & Proposed method & HPLC method & & \\
\hline $1(6 \mathrm{hr})$ & $18.12 \pm 0.46$ & $17.91 \pm 0.58$ & 1.56 & 45.1 \\
\hline $2(12 \mathrm{hr})$ & $8.22 \pm 0.29$ & $8.11 \pm 0.17$ & 1.03 & 32.2 \\
\hline $3(24 \mathrm{hr})$ & $2.99 \pm 0.09$ & $2.24 \pm 0.08$ & 0.89 & 30.1 \\
\hline $4(36 \mathrm{hr})$ & $0.40 \pm 0.01$ & $0.41 \pm 0.02$ & 0.55 & 30.0 \\
\hline \multicolumn{5}{|c|}{$\begin{array}{l}{ }^{a} \text { Average } \pm \text { S.D. of six determinations. }{ }^{b} \text { The urine samples are collected at } 6,12,24 \text { and } 36 \mathrm{hr} \text { after oral administration of CIP tablets in a clinic, done by a } \\
\text { healthy subject. }{ }^{{ }^{\circ}} \mathrm{P} \text { value of the comparison test. }\end{array}$} \\
\hline \multirow[t]{3}{*}{ Table 8: } & ination of CIP in huma & & & \\
\hline & \multicolumn{2}{|l|}{ Human urine } & & \\
\hline & Amount added & \multicolumn{2}{|c|}{ Amount found } & Recovery \\
\hline Sample & $\left(\mu \mathrm{g} \mathrm{ml}^{-1}\right)$ & \multicolumn{2}{|c|}{$\left(\mu \mathrm{g} \mathrm{ml}^{-1}\right)$} & $(\%) \pm$ S.D ${ }^{a}$ \\
\hline Urine 1 & 0.002 & \multicolumn{2}{|c|}{0.001} & $97.22 \pm 1.1$ \\
\hline Urine 2 & 0.031 & \multicolumn{2}{|c|}{0.029} & $94.98 \pm 0.8$ \\
\hline Urine 3 & 0.120 & \multicolumn{2}{|c|}{0.111} & $95.32 \pm 1.3$ \\
\hline Urine 4 & 0.559 & \multicolumn{2}{|c|}{0.528} & $96.01 \pm 1.4$ \\
\hline $\mathrm{X} \pm$ S.D. & & & & $95.9 \pm 1.1$ \\
\hline
\end{tabular}

${ }^{a}$ Average \pm S.D. of five determination. 
Am. J. Applied Sci., 3 (8): 1952-1960, 2006

Table 9: Comparison with other proposed methods for the determination of ten FQs

\begin{tabular}{|c|c|c|c|c|c|}
\hline Technique & Studied & L. $r^{a}$ & L.D ${ }^{\mathrm{b}}$ & Application & Reference \\
\hline Spectrophotometry & AMI & $10-60$ & 2.2 & $\begin{array}{l}\text { Commercial } \\
\text { formulations }\end{array}$ & {$[16]$} \\
\hline Spectrophotometry & CIP & $10-70$ & 2.1 & $\begin{array}{l}\text { Commercial } \\
\text { formulations }\end{array}$ & {$[16]$} \\
\hline Spectrophotometry & OFL & $5-35$ & 3.7 & $\begin{array}{l}\text { Commercial } \\
\text { formulations }\end{array}$ & {$[15]$} \\
\hline Atomic spectrometry & PEF & $10-80$ & 4.8 & $\begin{array}{l}\text { Commercial } \\
\text { formulations }\end{array}$ & {$[16]$} \\
\hline Spectrofluorimetry & LEV & $20-300$ & 10 & Serum and urine & [35] \\
\hline Spectrofluorimetry & NOR & $10^{3}-10^{5}$ & 2740 & $\begin{array}{l}\text { Commercial } \\
\text { formulations }\end{array}$ & [36] \\
\hline Spectrofluorimetry & PEF & $16-3313$ & 1074 & Serum & [37] \\
\hline HPLC - FD & LOM & $10-1000$ & 10 & Plasma & [34] \\
\hline HPLC - FD & LEV & $15-5000$ & 16 & Plasma & [32] \\
\hline HPLC - FD & NOR & $70-2109$ & 70 & Plasma & [33] \\
\hline Capillary electro. & NOR & $800-4500$ & 200 & Plasma & [38] \\
\hline Capillary electro. & NOR & $4-800$ & 1.0 & Plasma & [38] \\
\hline \multirow[t]{4}{*}{ Spectrofluorimetry } & CIP & $4-140$ & 0.7 & Commercial & This work \\
\hline & NOR & $2-290$ & 1.2 & formulations & \\
\hline & OFL & $3-220$ & 0.9 & and urine & \\
\hline & LEV & $4-280$ & 0.4 & & \\
\hline
\end{tabular}

${ }^{\mathrm{a}}$ Linear dynamic range $\left(\mathrm{ng} \mathrm{ml}^{-1}\right){ }^{\mathrm{b}}$ Limit of detection $\left(\mathrm{ng} \mathrm{ml}^{-1}\right)$

Table 10: Effect of commonly used excipients on the determination of $\mathrm{CIP}\left(0.1 \mu \mathrm{g} \mathrm{mL}^{-1}\right)$

\begin{tabular}{lll}
\hline Drug $\left(0.1 \mu \mathrm{g} \mathrm{mL}^{-1}\right)$ & Excipients $\left(50 \mu \mathrm{g} \mathrm{mL}^{-1}\right)$ & Recovery $(\% \pm \text { S.D. })^{\mathrm{a}}$ \\
\hline Ciprohexal & Starch & $100.9 \pm 1.22$ \\
Ciprohexal & Lactose & $99.54 \pm 0.94$ \\
Ciprohexal & Glucose & $99.32 \pm 1.19$ \\
Ciprohexal & Fructose & $99.09 \pm 1.12$ \\
Ciprohexal & Sucrose & $100.7 \pm 1.31$ \\
Ciprohexal & Magnesium stearate & $100.1 \pm 0.98$ \\
\hline
\end{tabular}

${ }^{a}$ Average value \pm S.D. of five determinations

for the determination of studied drugs, described in the literature (Table 9), showed an improvement of about one order of magnitude against HPLC methods. The HPLC methods generally require complex and expensive equipment, provision for use and disposal of solvents, labor-intensive sample preparation procedures and personnel skilled in chromatographic techniques. For spectrofluorimetry through charge transfer react (CTF), its main advantage over HPLC methods ${ }^{[32-34]}$ is its rapidity; CTF possesses good analytical selectivity, higher capacity against blank interference and can improve the limit of detection when compared with spectrophotomeric methods ${ }^{[16]}$.

Effect of interfering substances: The assay results were unaffected by the presence of excipients as shown by the excellent recoveries obtained when analyzing the studied drugs in presence of commonly encountered excipients. Samples containing a fixed amount of the FQs $\left(0.1 \mu \mathrm{g} \mathrm{mL}^{-1}\right)$ and excipients $\left(50 \mu \mathrm{g} \mathrm{mL}^{-1}\right)$ were measured.

No interference was observed from commonly used excipients such as starch, lactose, glucose, fructose, sucrose and magnesium stearate (Table 10). This fact indicates good selectivity of the method for determination of the studied drugs in raw material and their dosage forms. Also, the fluorescence of $6 \mathrm{ng} \mathrm{mL}^{-1}$ for CIP solution was measured in the presence of some cations, typically in urine sample. $\mathrm{Ca}^{2+}, \mathrm{Mg}^{2+}, \mathrm{Na}^{+}$and $\mathrm{K}^{+}$do not cause interference at concentration ratio of cation /CIP > 1000 and $\mathrm{Zn}^{2+}, \mathrm{Cu}^{2+}, \mathrm{Al}^{3+}$ and $\mathrm{Fe}^{3+}$ interfere negatively at concentration ratio over 500, 300, 200 and 4, respectively, so no interference from the cations presence is expected.

\section{CONCLUSION}

The results obtained from the present study indicate that complex formation between the studied FQs and TFQ be employed in the spectrofluotimetric assay of AMI, CIP, DIF, ENO, ENR, LOM, LEV, NOR, OFL and PEF in dosage forms and human urine. The proposed methods are suitable for the routine quality control of the drug alone, in different pharmaceutical formulations and in human urine without fear of interference caused by the excipients expected to be present in pharmaceutical formulations or components of human urine.

\section{REFERENCES}

1. Martindale, 2002. The Extra Pharmacopoeia. $33^{\text {rd }}$ Edn., Royal Pharmaceutical Society, London.

2. Giuseppe, C, 1998. Analysis of fluoroquinolones in biological fluids by high-performance liquid chromatography. J. Chromatogr. A, 812: 343-367.

3. Samanidou, V.F.; Christodoulou, E. A. and Papadoyannis, I. N., 2005. Direct determination of five fluoroquinolones in chicken whole blood and in veterinary drugs by HPLC. J. Sep. Sci. 28(4), 325-331. 
4. Zhenling, Z., D. Huanzhong, H. Xianhui and C. Zhangliu, 2003. Simultaneous assay of fluoroquinolones in plasma by high-performance liquid chromatography. Beij. Chin., 36: 846-850.

5. You, F., L. Jin and H. Zhao, 1999. Determination of four fluoroquinolones in human plasma by highperformance liquid chromatography. Anal. Comm., 36: 231-233.

6. Lolo, M., S. Pedreira, C. Fente, B. Vazquez, C.M. Franko and A. Cepeda, 2005. The $\mathrm{pH}$ influence on the HPLC-retention of chemotherapeutic fluoroquinolone derivatives. J. Agr. Food Chem., 53: 2849-2852.

7. Robert, F.T., C.A. Robert, M.P. Frano and J.A. Longstreth, 1995. Determination of certain fluoroquinolones in bulk drug and dosage forms by high-performance liquid chromatography. J. Pharm. Biomed. Anal., 13: 1243-1248.

8. Shunde, L., L. Jiachuan, Z. Ruhong, C. Hongsheng and L. Rongling, 1998. Reversed-phase ion-pair high-performance liquid chromatographic determination of fluoroquinolones in human plasma. Yaox. Xueb, 33: 937-940.

9. Mascher, H.J. and C. Kikuta, 1998. J. Rapid HPLC assay of fluoroquinolones in clinical specimens. Chromatogr. A, 812: 381.

10. El-Anwar, F., 2000. Multiresidue determination of fluoroquinolones in shrimp by liquid chromatography-fluorescence-mass spectrometry. J. Drug Res., 23: 79-82.

11. Montay, G., Y. Blain, F. Roquet and A. Hir, 1983. Utility of HPLC for analysis of certain fluoroquinolones. J. Chromatogr. B, 272: 359.

12. Mostafa, S., M. El-Sadek and.E. Awadalla, 2002. Spectrophotometric determination of ciprofloxacin, enrofloxacin and pefloxacin through charge transfer complex formation. J. Pharm. Biomed. Anal., 27: 133-142.

13. Zhao, F.L., B.Z. Xu, Z.Q. Zhang and S.Y. Tong, 1999. Analysis of certain fluoroquinolones by charge transfer reactions. J. Pharm. Biomed. Anal., 21: 355.

14. Patel H.; Fursule, R. A. and Talele, G. S. 2005. Spectrophotometric method for the determination of lomefloxacin hydrochloride. Indian Pharm. ), 4(40), 67-68.

15. Salem, H., 2004. Colorimetric and atomic absorption spectrometric determination of some fluoroquinolone derivatives. Sci. Pharm., 72: 5171.

16. Salem, H., 2005. Spectrofluorimetric, atomic absorption spectrometric and spectrophotometric determination of some fluoroquinolones. Am. J. Appl Sci., 2: 719-729.
17. Espinosa M. A.; Munoz P. A.; Canada, F. and Gonzalez G. D. 2005. Determinations of fluoroquinolones in urine by extractive spectrophotometry and photoinduced spectrofluorimetry using multivariate calibration. Anal. Biochem. 347(2), 275-286.

18. Vilchez, J.L., O. Ballesteros, J. Taoufiki, G.S. Palencia and A. Navalon, 2001. A novel spectrofluorimetric method for determination of lomefloxacin based on supramolecular inclusion complex between it and p-sulfonated calyx[4]arene. Anal. Chim. Acta, 444: 279.

19. Veiopoulou, C.J., P.C. Lounici and E.S. Lianidou, 1997. Fluorimetric analysis of certain fluoroquinolones. J. Pharm. Biomed. Anal., 15: 1839.

20. Jaber, A.M.Y. and A. Lounici, 1994. Polarographic analysis of certain fluoroquinolones. Anal. Chim. Acta, 291: 53.

21. Rizk, M., F. Belal, F. Ibrahim, S. Ahmed and N. El-Enany, 2000. Spectrofluorimetric analysis of certain 4-quinolone in pharmaceuticals and biological fluids. J. Pharm. Biomed. Anal., 24: 211.

22. Christian, H. and B. Gottfried, 2001. Development of capillary electrophoresis methods for the analysis of fluoroquinolones and application to the study of the influence of humic substances on their photodegradation in aqueous phase. J. Chromatogr. B, 754: 168-178.

23. du, L.M., J.P. Wang and Y.H. Liu, Charge transfere complexation reactions of some fluoroquinolones 2002. J. Anal. Chem., 30: 658.

24. du, L.M., Q.Q. Xu and J.M. Yuan, 2003. Fluorescence spectroscopy determination of fluoroquinolones by charge-transfer reaction. J. Pharm. Biomed. Anal., 33: 693-698

25. du, L.M., Z.F. Fan and R.F. Zang, 2003. Spectrophotometric determination of some fluoroquinolones in pharmaceutical dosage forms. Spec. Anal., 23: 328.

26. du, L.M., A.P. Lin and Y.Q. Yang, 2004. Spectrofluorimetric determination of certain fluoroquinolone through charge transfer complex formation. Anal. Lett., 37: 2175-2188.

27. du, L.M., H.Y. Yao and M. fu, 2005. Spectrofluorimetric study of the charge-transfer complexation of certain fluoroquinolones with 7,7,8,8-tetracyanoquinodimethane. Spectro. Act. A, 61: 281-286.

28. Foster, R., 1969. Organic Charge-transfer Complexes. Academic Press, London, pp: 623755.

29. Job, P., 1936. Ann. Chim., 16: 97. 
30. Yoe, J.H. and A.L. Jones, 1944. Ind. Eng. Chem. Anal. Ed., 16: 111.

31. Wong, F.A., S.J. Juzwin and S.C. Flor, 1997. Chromatographic determination

of fluoroquinolones J. Pharm. Bionef. Anal.,15: 765771.

32. Ulrike, N., J. Christion, F. Martin, J. Markus and M. Bernhard, 2002. High performance liquid chromatographic analysis of fluoroquinolones. Anal. Chim. Acta, 463: 199-206.

33. Mascher, H.J. and C. Kikuta, 1998. Determination of temafloxacin, sarafloxacin, and difloxacin in bulk drug and dosage forms by high-performance liquid chromatography. J. Chromatogr. A, 812: 381-385.

34. Foster, R.T., R.A. Carr, F.M. Pasutto and J.A. Longstreth, 1995. Development and validation of a reversed-phase HPLC method for the analysis of gatifloxacin in bulk and its pharmaceutical formulations. J. Pharm.Biomed. Anal., 13: 12431248.
35. Gonzalez, J.A.O., M.C. Mochon and F.J.B. Rosa, 2000. Analytical study of fluoroquinolones in biological fluids. Talanta, 52: 1149-1158.

36. Borrego, M.C., M.C. Diaz, I. Bernabi and D.C. Diaz, 1996.Spectrophotometric analysis of fluoroquinolones in dosage forms. J. Pharm. Bionef. Anal., 41: 977-982.

37. Veiopoulou, C.J., P.C. Loannou and E.S. Lianidou, 1997. Determination of in vitro synergy when three antimicrobial agents are combined against Mycobacterium tuberculosis. J. Phar. Bionef. Anal., 15: 1839-1844.

38. Hernandez, M., F. Borrull and M. Calull, 2000. Biological assay and liquid chromatographic method for analysis of moxifloxacin in tablets and biological fluids. J. Chromatog. B, 742: 255265. 